\title{
The Knowledge Governance Approach
}

\author{
Foss, Nicolai J.
}

Document Version

Final published version

Publication date:

2005

License

CC BY-NC-ND

Citation for published version (APA):

Foss, N. J. (2005). The Knowledge Governance Approach. Center for Strategic Management and Globalization. SMG Working Paper No. 1/2005

Link to publication in CBS Research Portal

\section{General rights}

Copyright and moral rights for the publications made accessible in the public portal are retained by the authors and/or other copyright owners and it is a condition of accessing publications that users recognise and abide by the legal requirements associated with these rights.

\section{Take down policy}

If you believe that this document breaches copyright please contact us (research.lib@cbs.dk) providing details, and we will remove access to the work immediately and investigate your claim. 


\title{
The Knowledge Governance Approach
}

\author{
Nicolai J. Foss \\ SMG WP 1/2005
}

September 2005 
SMG Working Paper No. 1/2005

September 2005

ISBN: TBA

Center for Strategic Management and Globalization Copenhagen Business School

Porcelænshaven 24

2000 Frederiksberg

Denmark

www.cbs.dk/smg 


\title{
The Knowledge Governance Approach
}

\author{
Nicolai J. Foss \\ Center for Strategic Management and Globalization \\ Copenhagen Business School \\ Porcelænshaven 24B, 2nd fl.; 2000 Frederiksberg; Denmark \\ njf.smg@cbs.dk \\ and \\ Department of Strategy and Management \\ Norwegian School of Economics and Business Administration \\ Breiviksveien 40; N-5045; Bergen; Norway
}

8 September 2005

Prepared for a special issue of Organization.

\section{Acknowledgments}

This paper was first given as a talk at a session at the 2005 EGOS conference in Berlin. I am grateful to participants in the session for comments, and to Andreas Scherer for urging me to put my thoughts in a paper format. Thanks to Yvonne Borkelmann for research assistance.

JEL Code: L1, L2, M1

Keywords: Governance, knowledge management, organizational economics 


\title{
The Knowledge Governance Approach
}

\begin{abstract}
An attempt is made to characterize a "knowledge governance approach" as a distinctive, emerging field that cuts across the fields of knowledge management, organisation studies, strategy and human resource management. Knowledge governance is taken up with how the deployment of administrative apparatus influences knowledge processes, such as sharing, retaining and creating knowledge. It insists on clear behavioural foundations, adopts an economizing perspective and examines efficient alignment between knowledge transactions with diverse characteristics and governance structures and mechanisms with diverse capabilities of handling these transactions. Various open research issues that a knowledge governance approach may illuminate are sketched. Although knowledge governance draws clear inspiration from organizational economics and "rational" organization theory, it recognizes that knowledge represents various challenges to more "closed" social science disciplines, notably economics.
\end{abstract}




\section{An Emerging Field}

The purpose of this paper is to paint a portrait of an emerging field that cuts across the knowledge management, human resource management, organization and strategy fields. This field submits that knowledge processes (i.e., the creation, retention, and sharing of knowledge) (Argote 1999) can be influenced, and to a certain extent directed, through the deployment of administrative apparatus, such as organization structure and coordination mechanisms. This field may well be called "knowledge governance" to signify that it is taken up with the interplay between knowledge processes and organizational processes, and also to signify its indebtedness to organizational economics. ${ }^{1}$ The field of knowledge governance has partly arisen as a response to some clear knowledge gaps in the knowledge management field (and indeed in broader general concern with knowledge that has characterized management studies in the last one and a half decade). Most importantly, the KM field has paid surprisingly little attention to organizational theory - surprising, that is, because KM processes take place in an organizational context, and the use of organizational theory to elucidate the boundary conditions, etc. of such processes would appear to be natural. In contrast, the knowledge governance approach makes ample use of existing organizational theory. In particular, organizational economics looms large, although representatives of the knowledge governance approach recognize that knowledge itself is not trivial to analytically approach and that in some ways it challenges more "closed" social science approaches, such as (formal) mainstream economics (e.g., Grandori and Kogut 2002).

\section{Why Knowledge Governance?}

\section{Fellow-Travellers in the Knowledge Movement}

\footnotetext{
1 The origin of the term "knowledge governance" is somewhat unclear. It seems, however, that the first use of it is in Grandori (1997). For attempts to characterize knowledge governance as a distinctive approach that are related to this paper, see Foss and Mahnke (2003), Foss, Husted, Michailova and Pedersen (2005), and Foss (2005a). Grandori and Kogut (2002) also contains many pertinent observations.
} 
It is no overstatement to say that "knowledge" has been all the rage for more than a decade in a number of fields in management studies (e.g., Grandori and Kogut 2002; Eisenhardt and Santos 2003). A veritable "knowledge movement" that cuts across traditionally separate disciplines in business administration has emerged. The strategy field has witnessed a proliferation of approaches that all place knowledge assets centerstage (e.g., Grant 1996); the international business field is in the process of developing a view of the multinational corporation as a knowledge-based entity (Tallman 2004); network ideas that stress connections between knowledge nodes are becoming increasingly influential (Kogut 2000); and, of course, "knowledge management" has become not only a huge body of literature, but also a widespread organizational practice (Easterby-Smith and Lyles 2003; Spender 2005).

Those who are engaged in building the knowledge governance approach — and a more precise identification will be provided later - welcome the centrality ascribed to knowledge in these diverse approaches. They agree that for a number of reasons (see Foss 2005a: Chapter 1 for a more comprehensive discussion), the management of knowledge assets of whatever kind has become a critical issue. They agree that it is meaningful to speak of different kinds of knowledge, each implying different management needs. And they also agree that no single established business administrative field or social science perspective is likely to carry us all the way towards a comprehensive understanding of the management of knowledge. In other words, those who subscribe/contribute to the knowledge governance are sympathetic fellow-travellers in the overall knowledge movement.

\section{Gaps in Knowledge Research}

Nevertheless, there are a number of features of the knowledge movement in general and of knowledge management in particular that are highly problematic. Here is an inventory of the kind of problems that those who may subscribe to a knowledge governance approach may diagnose.

At a fundamental level, it is something of a puzzle that it has become almost axiomatic that knowledge must always be at the basis of competitive advantage, for relatively little hard, quantitative evidence speaks directly to the issue. Part of the 
reason is, of course, that the links between knowledge assets, or organizational processes and practices involving such assets, and competitive advantage are very complex, and perhaps only fully intelligible through painstaking qualitative research.

In particular, the links are mediated by organization, by such means as the deployment of information systems, incentive schemes, allocations of decision rights ("authority"), and so on. For example, the attempt to better exploit certain knowledge assets through knowledge sharing is typically implemented through various kinds of administrative machinery. Responsibility for the operation may be delegated to a manager (allocation of decision rights), incentives for knowledge sharing may be set up, monitoring mechanisms that make sure that knowledge that is shared (and for which rewards are paid) is actually relevant knowledge, employees may have to be incented to actually search for knowledge, etc.

All of this is costly. However, surprisingly such costs are almost universally ignored in the knowledge management field (Foss and Mahnke 2003). Moreover, alternative kinds of administrative apparatus can be deployed to influence knowledge processes. But the relevant alternatives are seldom confronted in the knowledge management field. Relatedly, the question of whether, for example, knowledge sharing is always beneficial is seldom raised, at maximum knowledge sharing is implicitly assumed to be desirable; thus, explicit awareness of a tradeoff in knowledge sharing efforts is seldom encountered. However, a relevant alternative to knowledge sharing may often be more delegation of decision rights: If the problem is to make better use of existing knowledge, it may be better to allow the employees who hold this knowledge to make better use of it than to spread it to the rest of the organization. What is best depends, of course, on the net benefit associated with each alternative. However, such comparative assessments are virtually never performed in the KM field. 
To be sure, organization issues do get mention in the KM field. ${ }^{2}$ But often, and perhaps usually, organization is introduced, as it was, in the aggregative mode. Thus, theorists discuss the role of "communities of practice" (Brown and Duguid 1998) for influencing knowledge management tasks. In general, there is a tendency to reason in terms of aggregates or collectives in large parts of the knowledge movement. Much of the emphasis on capabilities, dynamic capabilities etc. represent this (Felin and Foss 2005). However, such a focus on collectives risk obscuring the real knowledge management task, which - like all managerial practice (Barnard 1938), — must begin with the individual.

\section{A Signallement of the Knowledge Governance Approach}

\section{Knowledge and Organization}

Assuredly, many writers have argued that organization is responsive to knowledge and that in turn organization may shape knowledge. Thus, on a fundamental level the information-processing emphasis in organization theory of the 1960s and 1970s illustrates the first causality, and earlier, Hayek's (1945) famous argument concerning the need for decentralization when relevant knowledge is "knowledge of time and circumstance" makes a similar point on an even more abstract level. Less abstractly, the innovation management literature has long stressed that such organizational issues as role definition, team composition, the distribution of authority, etc. should be very much responsive to the nature of the development effort.

However, organization also shapes knowledge. Again at a fundamental level, the organizational division of labour implies that processes of knowledge creation become path-dependent. As Brian Loasby (1976: 133) perceptively noted, an organizational structure “... not only determines where an organization's problems

\footnotetext{
2 The "knowledge-based theory of the firm" (Grant 1996) has not yet made the move from basic conceptualization to theory that clearly links characteristics of knowledge and of knowledge processes to organization; therefore, it is not a predictive theory and not one that is directly relevant to managers.
} 
are worked on, but also helps to determine what problems they shall be, how they are defined, and what solutions will be attempted." Thus, Clark and Fujimoto (1991) pointed out that building "integrating mechanisms," such as stage-overlapping product development processes and embedding these organizationally would facilitate thick communication across departments.

Many other points of reference can be found in the strategy and organization literatures. More recently, there has been a proliferation of ideas on, for example, alliances and joint ventures as vehicles for knowledge-building (Hamel 1991), internal venturing as means of accomplishing the same goal (Eisenhardt and Brown 1998), of high-performance HRM practices as driving innovation performance (Laursen and Foss 2003), on the "differentiated MNC" as a means of superior leverage of knowledge (Hedlund 1994), on "organizational knowledge structures" (Lyles and Schwenk 1992), and much else. These ideas all relate organization and knowledge issues on some level and to some extent. They are, however, very different and derived from different underlying base disciplines. It is not clear what unites them except a broad concern with the relation between organization and knowledge (Foss, Husted, Michailova and Pedersen 2005).

However, some synthetic attempts do exist. Pondering the issue of what "knowledge approaches can contribute to organizational theory," Grandori (Grandori and Kogut 2002: 225) recently observed that what has been added is “... a new 'contingency' factor for understanding organizational arrangements ... Knowledge complexity, differentiation, and specialization, complementarity and interdependence are emerging as important contingencies affecting effective organization and governance solutions." It is the contention of the present paper that it is possible to go even further and posit the existence of an emerging, distinctive approach to knowledge governance.

\section{Some Representative Knowledge Governance Contributions}

As a first take on an identification of the emerging knowledge governance approach, consider the following papers, all of which qualify as contributions to the knowledge governance approach. 
Margit Osterloh and Bruno Frey "Motivation, Knowledge Transfer, and Organizational Forms" (2000). The key point in Osterloh and Frey is that knowledge transfer is intimately connected to motivation which in turn is strongly influenced by specific organizational designs. The authors observe that firms increasingly introduce market elements to exploit the advantages of price mechanisms, by making exchanges between departments or actors more explicit and enabling them to reward according to the contribution to a firm's profit. The contribution of an employee's tacit knowledge to a team output however, cannot be measured and therefore paid accordingly. In tasks such as generating and transfer of knowledge, goals are difficult to formulate and task completion cannot be attributed to a particular employee. If knowledge is largely tacit and its diffusion is crucial to a joint output, the exchange of knowledge should remain inside a work team and not be outsourced or dissected into a profit centre. Since the transfer of tacit knowledge can not be assured by complete contracts and at the individual level an employee cannot be sanctioned for holding back tacit knowledge, it follows that in the absence of intrinsic motivation free-riding will take place. However, firms have access to mechanisms (that markets don't) to manage intrinsic motivation, such as participation which signifies agreement on common goals and raises employees' self-determination, thereby strengthening intrinsic motivation and personal relationships, which allows for establishing psychological contracts based on emotional loyalties, which in turn raise the intrinsic motivation to cooperate. Osterloh and Frey conclude that firms should perhaps be seen in a new light, namely as institutions that are better capable of managing motivation than the market.

Anna Grandori "Neither Hierarchy nor Identity: Knowledge-Governance Mechanisms and the Theory of the Firm" (2001). Grandori analyses the mechanisms that govern the transfer, sharing and integration of knowledge between and within firms. Firms have enriched their knowledge management systems with explicit mechanisms to provide incentives for knowledge integration. Grandori finds that not only hierarchical or communitarian mechanisms are usually applied, but also price-based (market-like) contracts and decentralized, but not identity based mechanisms. She concludes that the portfolio of mechanisms effectively employable 
between firms to link nodes of specialized knowledge can hardly be distinguished from those mechanisms employable within firms. Furthermore, the different knowledge governance mechanisms are evaluated according to their cognitive possibility and their relative cost. Grandori proposes a two-tier assessment of mechanisms in which the first tier is made up of "possibility theorems" of the applicability domain of mechanisms and the second tier consist of comparative propositions on the superiority of the different feasible mechanisms. Characteristics of the relation between knowledge nodes which can influence the cognitive possibility are knowledge differentiation, knowledge complexity and degree of conflict of interests. ${ }^{3}$ A framework, in which these three antecedents are represented on three axes, is proposed and the antecedents are labelled either as high or low.

\section{Julian Birkinshaw, Robert Nobel and Johan Ridderstråle "Knowledge as a} Contingency Variable: Do the Characteristics of Knowledge Predict Organization

Structure?" (2002). Birkinshaw et al. examine whether the characteristics of a firm's knowledge base influence the choice of organizational structure. Two dimensions of knowledge are examined: observability (i.e., how easy is it to understand the activity by looking at and examining different aspects of a process or final product) and system embeddedness (i.e., the extent to which the knowledge in question is a function of the system or context in which it is embedded). The empirical research is carried out on a data set obtained from 110 R\&D unit managers in 15 Swedish multinational firms. Organizational structure is conceptualized by two factors: the autonomy of the R\&D unit (i.e., the extent to which the unit is able to make strategic decisions without the involvement of corporate headquarters) and level of interunit integration (i.e., the state of collaboration among units, and the techniques used to achieve this collaboration). Birkinshaw et al. find that system embeddedness is the strongest predictor of interunit integration $(p<0.001)$ and also for R\&D unit

\footnotetext{
${ }^{3}$ Differentiation is measured as a factor, made up of several correlating variables (e.g. diversities in languages, differing perceptions of relevant information etc.) and expected to generate communication impasses and potential for conflict. Complexity is distinguished into computational (number of elements and possible connections) and epistemic complexity (difficulty of observing and diagnosing cause-effect relations). Conflict of interest is distinguished into low (homogenous or complementary interests) and high (all highly competitive games).
} 
autonomy ( $\mathrm{p}<0.004)$. Observability is significant for interunit integration, but only at $p<0.05$ and not statistically significant for R\&D unit autonomy.

Nicolai J. Foss "Selective Intervention and Internal Hybrids: Interpreting and Learning from the Rise and Decline of the Oticon Spaghetti Organization" (2003.) Infusing hierarchies with elements of market control has become a much-used way of simultaneously increasing entrepreneurialism and motivation in firms. However, this paper argues that such "internal hybrids," particularly in their radical forms, are inherently hard to successfully design and implement, because of a fundamental incentive problem of establishing credible managerial commitments to not intervene in delegated decision-making. This theme is developed and illustrated, using the case of the world-leading hearing aids producer, Oticon. In the beginning of the 1990s, Oticon became famous for its radical internal hybrid, the "spaghetti organization." Recent work has interpreted the spaghetti organization as a radical attempt to foster dynamic capabilities by organizational means, neglecting, however, that about a decade later, the spaghetti organization has given way to a more traditional matrix organization. In contrast, this paper adopts a knowledge governance lens that suggests that a strong liability of the spaghetti organization was the above incentive problem: Frequent managerial meddling with delegated rights led to a severe loss of motivation, and arguably caused the change to a more structured organization.

Jackson Nickerson and Todd Zenger "A Knowledge-based Theory of the Firm - The Problem-solving Perspective" (2004). Nickerson and Zenger seek to explain how alternative organizational forms influence the efficient production and protection of valuable knowledge. The unit of analysis for knowledge generation is a specific problem, whose value is determined by the values in the array of possible solutions and the cost of discovering a particularly valuable problem. The solution to complex problems is assumed to represent unique combinations or syntheses of existing knowledge. Problems differ according to their decomposability. Decomposable problems involve limited interaction, whereas non-decomposable problems involve extensive interaction. This has important implications for the type of searching for a 
solution. Directional search refers to classic trial and error search. It is efficient only for decomposable activities. Heuristic search refers to a group or team cognitively evaluating probable consequences of design choices.

Non-decomposable problems require individuals to share their specialized knowledge. The ability or motivation to share knowledge is impeded by two conditions: humans are cognitively constrained in the speed with which they learn and are prone to self-interest. The wide distribution of knowledge in conjunction with self-interest leads to two knowledge-related exchange hazards: knowledge appropriation and strategic knowledge accumulation. Consequently, efficiency considerations dictate the selection of an optimal governance mechanism and the provision of incentives. Three distinct governance mechanisms and their suitability for problems with differing characteristics are examined: markets, authority based hierarchies and consensus based hierarchies. Briefly, markets are ideally suited when problems are decomposable and directional search is desired; consensusbased hierarchy creates high organizational costs and should only be adopted when the benefits for consensus are high, which is for problems that are highly complex and non-decomposable; finally, authority-based hierarchy is superior to markets in supporting heuristic search, but inferior in supporting directional search. The authors propose that authority based-hierarchies are best suitable for a range of problems that are moderately complex.

\section{Fundamental Ideas}

The above papers share a number of commonalities which makes it meaningful to think of them as representatives of an emerging approach. An attempt is made in the following to identify these commonalities.

Microfoundations. It is characteristic of the above contributions that they are explicitly (e.g., Osterloh and Frey; Grandori) or more implicitly (Foss; Birkinshaw, Nobel and Ridderstråle) founded on methodological individualism. Thus, explanation starts with the individual, even though it may be permissible to introduce more collective concepts (e.g., organization structure) in the analysis. However, methodological individualism implies a reluctance to make use of 
collective concepts without micro-foundations, such as "capabilities." Instead, explicit micro-foundations are sought. This implies modelling (i.e., making specific assumptions about) individual agents' preferences, knowledge, incentives, etc. No doubt, such an approach is to some extent influenced by one's discipline; thus, most economists and all rational choice sociologists are methodological individualists.

However, one can also see the emphasis on individualistic foundations as an attempt to meet the lacunae left in the knowledge movement by the overriding emphasis on collective constructs. As Argote and Ingram (2000: 156) lamented, to the extent that there has been progress in studying knowledge as the basis of competitive advantage, "... it has been at the level of identifying consistencies in organizations' knowledge development paths and almost never at the level of human interactions that are the primary source of knowledge and knowledge transfer."

The knowledge governance approach attempts to address this "primary source" by taking an explicitly individualistic approach. For example, the fundamental idea of Osterloh and Frey (2000) is understandable only if the analysis explicitly begins from individual motivation. The point is that these contributions develop insights that simply cannot be reached in lieu of an individualistic starting point.

Unit of analysis(es). A constant source of confusion in the knowledge movement at large has been the absence of a clear identification of a unit of analysis (cf. Williamson 1999; Felin and Foss 2005). Is it routines (Nelson and Winter 1982), or capabilities (Richardson 1972), or dynamic capabilities (Teece, Pisano and Shuen 1997), or practices (Spender 2005), or knowledge assets (Winter 1987), or some piece of "intellectual capital" as in much of the knowledge management literature? Particularly in the strategy and organization parts of the overall knowledge movement, the emphasis has been on the more collective constructs, such as routines or capabilities. Sometimes these are seen as hierarchically related (as in Nelson and Winter 1982; Winter 2003). However, other parts of the knowledge movement utilize other collective constructs, such as communities of practice, and it is not clear how these collective constructs relate to routines or capabilities. 
More generally, it is not clear how they relate to micro-level constructs (Felin and Foss 2005). This means that significant parts of the knowledge movement works with an explanatory apparatus where collective outcomes (e.g., competitive advantage, knowledge sharing performance, overall knowledge creation, the boundaries of the firm) are explained in terms of collective concepts (e.g., capabilities, communities of practice) without an attempt to explicitly incorporate lower levels of analysis.

The knowledge governance approach is agnostic on the precise nature of the unit of analysis. This can vary, depending on what is the purpose of the analysis. However, it does insist that the unit of analysis is related to individual choice behaviour. Both taking the "knowledge transaction" (Grandori 2001) or the "problem" as the unit of analysis is consistent with this. It is more questionable whether taking the capability as a unit of analysis is.

Dimensionalizing knowledge. Corresponding to the lack of clarity on what is the unit of analysis in significant parts of the knowledge movement is a lack of clear dimensionalization of the various knowledge constructs. The many studies of interfirm imitation and intra-firm knowledge transfer (e.g., Maritan and Brush 2003) tend to develop dimensions of, say, capabilities in an inductive manner and the explicit or implicit dimensionalizations differ from study to study. Numerous taxonomies and distinctions have been produced on an a priori basis. An early contribution was Winter (1987) with its distinctions between tacitness vs. explicitness, system-quality vs. stand-alone, teachability vs. non-teachability, and complexity vs. noncomplexity. The Winter distinctions have been the basis for significant subsequent empirical work (Kogut and Zander 1993; Birkinshaw, Nobel and Ridderstråle 2002), and may be the best bid at a rather generally accepted dimensionalizing of knowledge. Existing contributions to the knowledge governance approach are quite consistent with the Winter approach (e.g., Birkinshaw, Nobel and Ridderstråle 2002; Nickerson and Zenger 2004).

Transactional problems. Given a characterization and dimensionalization of the unit of analysis in terms of knowledge, the scene is set for an examination of the 
transactional problems that knowledge produces. Processes of creating, sharing, transferring, knowledge etc. are highly intertwined with "ordinary" business processes. Although knowledge sharing and knowledge creation may be partly unintended by-products of more conventional business processes, as, for instance, in conventional accounts of the learning-by-doing phenomenon, ${ }^{4}$ it is conceptually and theoretically — and often also practically — possible to think of knowledge processes as distinct processes.

Knowledge processes have a number of salient features that set them apart from many "ordinary" business processes (e.g., coordinating logistics, running an assembly line, making a contract with a supplier, etc.) (Osterloh and Frey 2000). Thus, Foss, Husted, Michailova and Pedersen (2005) argue that knowledge processes are particularly challenging to analytically approach (and for similar reasons: to manage) because of, inter alia, the unavoidable emergence of "novelties" (unforeseen contingencies) in all learning processes; the significant elements of "team production" in knowledge processes (Alchian and Demsetz 1972; Lindenberg 2003), that is, it is particularly hard and costly to measure the marginal product of each participant in the processes of creating and sharing knowledge... difficulties of ascertaining the outcome; problems of asymmetric information are particularly severe because much of the relevant knowledge is tacit so that it may be particularly hard to design mechanisms for eliciting such knowledge; detailed contingent plans for knowledge processes may be extremely costly to draft (Holmström 1989); etc.

While these characteristics may characterize all business processes, they are more strongly present in knowledge processes. Per implication knowledge processes need particular ways of organizing and governing that can accommodate the peculiar informational, cognitive and motivational aspects of knowledge processes (Osterloh and Frey 2000; Grandori 2001; Lindenberg 2003).

Knowledge governance. As a positive approach knowledge governance examines alignment between knowledge transactions - which differ in their characteristics -

\footnotetext{
${ }^{4}$ The extent to which learning by doing is really an unintended byproduct or rather something quite consciously designed is critically discussed in REF?
} 
and governance structures and governance mechanisms - which differ in their competencies —, using efficiency as the explanatory principle (cf. Williamson 1996; Buckley and Carter 1996). As a practical and normative enterprise, knowledge governance means deploying administrative apparatuses that mitigate costs of creating and sharing knowledge owing to the above characteristics of knowledge (Heiman and Nickerson 2002: 98). Knowledge governance therefore means choosing governance structures (e.g., markets, hybrids, hierarchies) and governance and coordination mechanisms (e.g., contracts, directives, reward schemes, incentives, trust, management styles, organizational culture, etc.), so as to maximize the net benefits from processes of transferring, sharing and creating knowledge. Governance structures and governance mechanisms are important because they define the incentives and coordinate the actions of organizational members in knowledge processes (Foss and Mahnke 2003).

\section{Research Themes and Open Issues}

To see that there is a need for a knowledge governance approach, consider the following two examples of clearly important phenomena, namely 1) the governance of knowledge intensive firms (Starbuck 1992) or perhaps more precisely, "human capital organizations," and 2) the importance of knowledge for competitive advantage. These are not only important phenomena, they would also strike even the casual observer as phenomena to which a great deal of research effort has been devoted. However, a knowledge governance approach reveals the existence of serious lacunae in our knowledge about these and suggests how to remedy the knowledge gaps.

\section{Governance of Human Capital Organizations}

What is here called "human capital organizations" are organizations where a significantly larger part of value added can be ascribed to human than to physical assets. They encompass organizations ranging from R\&D-intensive manufacturing

firms to professional services firms. They rely on scarce "expert talent," employ much-demanded "knowledge workers," and, in general, mark a shift to a more 
"knowledge-intensive" mode of production. The present paper critically discusses the changing requirements for organizational control in human capital organizations. In particular, it takes issue with an emerging thinking concerning this issue.

The changes with respect to an increasing human content of firms' productive inputs are often argued to take place in tandem with an increase of the "knowledgecontent" in outputs, a stepping up of innovative activity, an increasing differentiation of demand, increasing globalization, and increasingly inexpensive networked computing - complementary changes that are taken to indicate the emergence of the "knowledge economy" (Halal and Taylor, 1998; Prusac, 1998), or at least a new paradigm of "modern manufacturing" (Milgrom and Roberts 1990).

Fundamental changes in economic organization are also implied by the increased prevalence of human capital organizations, as reflected in notions of the "changing employment contract," "new organizational forms," "internal disaggregation," "the molecular form," etc. In particular, many scholars have argued that the boundaries of firms are being radically transformed, not just because firms increasingly disaggregate (i.e., outsource, spin-off, etc.), but also because the very notion of firm boundaries is becoming increasingly problematic as (inalienable) human capital increasingly dominates (alienable) physical capital as the most important category of productive capital (Foss 2002 critically evaluates this discussion). This is because control of physical capital cannot anymore be used to the same extent as a source of organizational control over human capital, that is, employees (as in Hart 1995; Rousseau and Shperling 2003).

As this suggests, the advent and increased prevalence of human capital organizations have profound implications for the application of organizational controls. In fact, according to a viewpoint that has almost acquired the status of conventional wisdom, human capital organizations may be differentiated from "traditional" firms in terms of organizational control by relying less on direction through the exercise of authority, eschewing high-powered performance incentives, 
and embracing "culture" and "clan" modes of organizational control (at least for the core group of employees) (e.g. Child and McGrath 2001; Coff 2001).

However, a completely contrary view can be found in Teece (2003). Teece explains how the organization of his own firm (Law and Economics Consulting Group, LECG), a professional services firm, is very much geared to the use of some modes of organizational control that lie as away as possible from the soft dimension. In particular, while indeed the traditional blunt authority-mechanism (supervision, order-giving) is "extremely weak" in this firm, very high-powered performance incentives are used. The two features are related, for by setting compensation for "experts" “... purely as a certain percentage $\alpha$ of the expert's own individual bill-out rate times hours worked (as accepted by the client)" (Teece 2003: 909), strong incentives are coupled with a small need for monitoring. Teece speculates that the specific organizational design of LECG (and there are many other features in addition to those briefly mentioned here) “... may well portend the future for professional service organizations endeavouring to leverage top talent" (p. 914).

The point is, of course, not that Teece is right and those who argue differently are wrong, or vice versa. It is rather that we do not have good stories that allow us to theoretically discriminate between these alternative accounts. For activities with certain specific attributes, the conventional wisdom may be right; for activities with other attributes, it may not. Perhaps parts of the answer can be found in the Osterloh and Frey (2000) idea that intrinsic motivation is crucial if the sharing of tacit knowledge is an important concern; in that case the Teece model with its strong emphasis on "extrinsic motivation" may not work well. At any rate, a knowledge governance perspective is needed for framing these issues, so that testable hypotheses can be derived.

\section{Knowledge and Competitive Advantage}

Strategic management may well be the field in business administration where knowledge approaches have been developed and applied with the greatest success (in terms of influence in the field) (e.g., Kogut and Zander 1992; Grant 1996; Spender 1996; Kogut 2000). Thus, the dominant resource-based view, while not logically 
committed to placing knowledge resources centerstage, nevertheless often does exactly this, the underlying arguments being that knowledge resources feed the renewal of competitive advantages and are particularly difficult to imitate. Thus, both the creation and the sustainability of competitive are conventionally seen as fundamentally rooted in knowledge resources. In particular, much interest has centred on constructs such as capabilities, and in recent years particularly dynamic capabilities (Teece, Pisano and Shuen 1997) that are argued to cause long-lived performance differentials across firms.

From a knowledge governance perspective such reasoning is, however, highly unsatisfactory. There are two reasons for this.

First, as suggested earlier, the underlying methodological collectivism flies in the face of the insistence on micro-foundations. To argue that an aggregate/collective outcome (i.e., the performance of the firm) can be explained in terms of another aggregate (capabilities or dynamic capabilities) is to make an explicit break with methodological individualism.

A recent attack on this collectivism has been launched by Lippman and Rumelt (2003) who point out that arguing that "firms" earn a residual return called "profits" is highly misleading. In particular, it obscures the complex process of appropriating value where the appropriation is not undertaken by firms (and certainly not by "capabilities") but by the firm's stakeholders that come equipped with different bargaining powers. Although this is not directly mentioned by Lippman and Rumelt, there is a feedback loop from the value appropriation of individual resource owners to value creation, because expectations with respect to how much of the rent stream can be appropriated will strongly influence a resource owners effort and investment incentives (Hart 1995). In this scheme, knowledge matters also because it is a prominent source of bargaining power.

Second, and relatedly, the collectivist capabilities perspective in strategy neglects organization at its peril. Although capabilities are (to the extent that they are defined) often taken to be organizational processes that enable managers to carry out certain key tasks (e.g., Helfat and Peteraf 2003), organization itself seems almost 
conspicuous by its absence in most capabilities work. By "organization" in a broad sense, may be understood the formal and informal allocation of decision (or property) rights (Jones 1983) and the mechanisms that enforce such rights. This rights allocation and the accompanying enforcement mechanisms constitute the distribution of authority, the attributes of administrative apparatus, organizational structure, and other aspects of formal organization, but clearly also relates to, for example, social ties and networks inside firms. All this matters, first, because an allocation of property rights is also an allocation of incentives (Barzel 1997), including incentives to search for knowledge, share knowledge, accumulate human capital, leverage knowledge capital, etc. (Foss and Mahnke 2003), and, second, because property rights also influence bargaining powers (Hart 1995). For example, social ties and networks - much emphasized in KM research - are important for understanding the links between knowledge and superior returns, not just because of their potentially beneficial effects on returns, but also because such ties and networks grant legitimacy to the claims that employees may make on rents (Coff 2005).

The bottom-line is that the link between knowledge and CA cannot be assessed independently of considering the multiple stakeholders in the firm nexus and the incentives and property rights these stakeholders confront. This brings organization directly into the picture. However, missing in contemporary strategic management theory is an appreciation and understanding of the organizational factors that mediate between knowledge resources and competitive advantages.

\section{Is Knowledge Governance Economics Imperialism?}

It should now be apparent that the knowledge governance approach draws rather strongly on organizational economics, that is, contract theory (Holmström and Milgrom 1991; Hart 1995), transaction cost economics (Coase 1937; Williamson 1996), nexus of contracts theory (Alchian and Demsetz 1972), and work on bargaining and influence costs in organizations (Milgrom 1988). In the context of firm organization, organizational economics directs attention to the coordination and incentive 
problems that are caused by the pathologies that unavoidably accompany an internal division of labour in a firm, such as asymmetric information, diluted performance incentives, measurement difficulties, bargaining problems, moral hazard, duplicative (redundant) efforts, etc. In turn, organizational economists have explained how a host of real-world organizational arrangements, such as various kinds of authority, payment schemes, delegation of decision rights, etc., serve to alleviate the severity of such problems. Their assessment of how well this is done is performed in terms of economic efficiency.

The use made of organizational economics in the knowledge governance approach may be too much for many traditional (if such exist) KM researchers. They may balk at the application of equilibrium and optimality ideas to knowledge processes. Furthermore, many KM researchers feel considerably more akin to the organizational behaviour stream of research in the organization studies field than to the organizational economics stream. It is therefore necessary to state that the knowledge governance approach is not an imperialistic economics undertaking. Economics imperialism, when used in a pejorative manner, means the application of mainstream economics modelling (i.e., applying the assumptions of stable preferences and maximization and the tool of equilibrium) to phenomena that they are inherently ill-suited to handle.

The knowledge governance approach fully recognizes that knowledge often and in many ways pushes the economics envelope. The point that knowledge processes are particularly challenging to approach analytically because, inter alia, they are particularly likely to be plagued by problems of asymmetric information (Foss, Husted, Michailova and Pedersen 2005) has already been mentioned. However, the problem goes deeper: The fundamental epistemology underneath mainstream economics, represented by the "state space model" is indeed extreme (cf. Samuelson 2005), and many standard assumptions of formal economics (e.g., the notion of "common knowledge") eliminates substantial parts of KM by assumption. Thus, knowledge governance scholars will have no problems with the proposition that 
bounded rationality needs to be taken much more seriously (See Grandori 2001; Nickerson and Zenger 2004).

However, the knowledge governance approach does argue that "knowledge processes," notably the creation and sharing of knowledge can be influenced by administrative means. The links between the influencing and the outcomes may be complicated. However, they are accessible to sustained scientific inquiry. And the knowledge governance approach entertains the working hypothesis that knowledge processes can be systematically influenced by "governance", that is, organizational control (Foss and Mahnke 2003). In elucidating this basic hypothesis, knowledge governance researchers have found organizational economics insights particularly helpful, while also recognizing that it is possible to apply ideas from agency theory, property rights, etc. without necessarily borrowing into the epistemological legacy of mainstream economics (for example, one can accept that property rights structure incentives without accepting the above axiom of omniscience).

Moreover, knowledge governance researchers recognize that organizational economics may often be a quite blunt instrument with which to attack issues of knowledge governance. Thus, most contributions to organizational economics assume that motivation is extrinsic (Osterloh and Frey 2000). Second, although not formally committed to this, organizational economics assumes that all motives are entirely selfish. This flies in the face of casual observation as well as experimental evidence (Fehr and Gächter 2000). An implication is that organizational economics may give the wrong picture of the actual amount of, for example, "altruistic" knowledge sharing in organizations. Third, organizational economics has traditionally not made much out of "soft" organizational issues, such as culture, organizational justice, psychological contracts, organizational communication and the like. Thus, while this body of theory provides an interesting framing of many of the basic reasons why knowledge processes may pose particular governance problems, it is also likely to provide a lopsided picture of knowledge processes in actual firms. Therefore, systematic attempts to include sophisticated treatments of motivation and cognition alongside organizational economics ideas are high on the 
knowledge governance agenda (cf. Osterloh and Frey 2000; Grandori 2001; Lindenberg 2003).

\section{Conclusions}

This brief essay has attempted to paint a portrait of an emerging field in the broader knowledge movement in management studies, here called the "knowledge governance approach." The approach deals with those issues relating to the interplay between knowledge processes and organization that seem to be so strongly under-researched (and unresolved) in conventional KM. Knowledge governance writers lean heavily if by no means exclusively on notions from organizational economics. In particular, it draws inspiration from the notion that a clear knowledge-based unit of analysis be identified and dimensionalized (e.g., a knowledge transaction or a problem) and that the relevant unit of analysis is aligned with governance structures and mechanisms on the basis of efficiency. Still, knowledge governance writers acknowledge that many issues relating to learning, perception, judgment and motivation may not be well be treated in a knowledge governance framework — and these may be better left for "traditional" KM research. For this reason, it is arguable that the knowledge governance approach and KM are complements rather than substitutes. 


\section{References}

Alchian, Armen A. and Harold Demsetz. 1972. "Production, Information Costs, and Economic Organization," American Economic Review 62: 772-795.

Argote, Linda, Sara L. Beckman, and Dennis Epple. 1990. “The Persistence and Transfer of Learning in Industrial Settings," Management Science 36: 140-154.

Argote, Linda. 1999. Organizational Learning: Creating, Retaining and Transferring Knowledge. Boston: Kluwer.

Argote, Linda and Ingram, Paul. 2000. Knowledge Transfer: A Basis for competitive advantage in firms. Organizational Behavior and Human Decision Processes, 82(1): 150-169.

Barzel Yoram. 1997. Economic Analysis of Property Rights. 2nd ed., Cambridge: Cambridge University Press.

Barnard, Chester I. 1938. The Functions of the Executive. Cambridge, MA: Harvard University Press.

Barney, Jay B. 1991. "Firm Resources and Sustained Competitive Advantage," Journal of Management 17: 99-120.

Birkinshaw, Julian, Robert Nobel and Jonas Ridderstråle. 2002. "Knowledge as a Contingency Variable: Do the Characteristics of Knowledge Predict Organization Structure?," Organization Science 13: 274-290.

Boulding, Kenneth E. 1966. "The Economics of Knowledge and the Knowledge of Econom ics," American Economic Review 56: 1-13.

Brown, J.S. and P. Duguid. 1998. "Organizing Knowledge," California Management Review 40 (3): 90-111.

Buckley, Peter J. and Martin J. Carter. 1996. “The economics of business process design: Motivation, information and coordination within the firm," International Journal of the Economics of Business, 33: 301-332.

Child, John and Rita McGrath. 2001. "Organizations Unfettered: Organizational Form in an Information Intensive Economy," Academy of Management Journal 44: 1135-1148.

Clark, Kim B. and T. Fujimoto. 1991. Product Development Performance: Strategy, Organisation and Management in the World Auto Industry. Boston: Harvard University Press.

Coase, Ronald H. 1937. “The Nature of the Firm,” Economica (1937): 386-405.

Easterby-Smith, Mark and Marjorie A. Lyles, eds. 2003. Handbook of Organizational Learning and Knowledge Management. Oxford: Blackwell Publishing.

Eisenhardt, Kathleen M. and Shona L. Brown. 1998. Competing on the Edge: Strategy as Structured Chaos. Boston: Harvard Business School Press. 
Eisenhardt, Kathleen M. and Filipe M. Santos. 2003. “Knowledge-Based View: A New View of Strategy," in Andrew Pettigrew, Howard Thomas and Richard Whittington, eds. Handbook of Strategy and Management. London: Sage.

Fehr, Ernst and Simon Gächter. 2000. "Fairness and Retaliation: The Economics of Reciprocity," Journal of Economic Perspectives, 14(3): 159-72

Felin, Teppo and Nicolai J. Foss. 2005. "Strategic Organization: A Field in search of micro-foundations," forthcoming," Strategic Organization

Foss, Nicolai J. 2005a. Strategy and Economic Organization in the Knowledge Economy: The Coordination of Firms and Resources," Oxford: Oxford University Press Foss.

Foss, Nicolai J. 2005b. "Knowledge and Organization in the Theory of the Multinational Corporation," forthcoming, Journal of Management and Governance.

Foss, Nicolai J., Kenneth Husted, Snejina Michailova, and Torben Pedersen. 2005. "Governing Knowledge Processes: Theoretical Foundations and Research Opportunities," unpublished manuscript.

Foss, Nicolai J. 2003. "Selective Intervention and Internal Hybrids: Interpreting and Learning from the Rise and Decline of the Oticon Spaghetti Organization." Organization Science 14: 331-349.

Foss, Nicolai J. and Volker Mahnke. 2003. “Knowledge Management: What Does Organizational Economics Contribute?," in Mark Easterby-Smith and Marjorie Lyles, eds. Handbook of Knowledge Management. Oxford: Basil Blackwell.

Foss, Nicolai J. and Torben Pedersen. 2002. "Sources of Subsidiary Knowledge and Organizational Means of Knowledge Transfer," Journal of International Management 8: 49-67.

Foss, Nicolai J. 2002. “Coase vs Hayek: Economic Organization in the Knowledge Economy," International Journal of the Economics of Busines 9: 9-36.

Grandori, Anna. 1997. "Governance Structures, Coordination Mechanisms and Cognitive Models," Journal of Management and Governance 1: 29-42.

Grandori, Anna. 2001. "Neither Hierarchy nor Identity: Knowledge Governance Mechanisms and the Theory of the Firm," Journal of Management and Governance 5: 381-399.

Grandori, Anna and Bruce Kogut. 2002. "Dialogue on Organization and Knowledge," Organization Science 13: 224-232.

Grant, Robert M. 1996. “Towards a Knowledge-based Theory of the Firm," Strategic Management Journal 17: 109-122.

Halal, W.E. and K.B. Taylor. 1998. Twenty-First Century Economics: Perspectives of Socioeconomics for a Changing World. New York: St. Martin's Press.

Hamel, Gary. 1991. "Competition for competence and inter-partner learning within international strategic alliances," Strategic Management Journal, 12: 83-103. 
Hart, Oliver. 1995. Firms, Contracts, and Financial Structure. Oxford: Oxford University Press.

Hayek, Friedrich A. von. 1945. "The Use of Knowledge in Society," in idem. 1948. Individualism and economic order. Chicago: University of Chicago Press.

Hedlund, Gunnar. 1994. “A Model of Knowledge Management and the N-Form Corporation," Strategic Management Journal 15: 73-91.

Heiman, Bruce and Jack A. Nickerson. 2002. “Towards Reconciling Transaction Cost Economics and the Knowledge-based View of the Firm: The Context of Interfirm Collaborations," International Journal of the Economics of Business 9: 97-116.

Helfat, Constance E. and Margaret A. Peteraf. 2003. “The Dynamic Resource-Based View: Capabilities and Lifecycles," Strategic Management Journal 24: 997-1010.

Holmström, B. 1989. "Agency Costs and Innovation," Journal of Economic-Behavior and Organization, 12: 305-27.

Holmström, Bengt and Paul Milgrom. 1991. "Multitask Principal-Agent Analysis: Incentive Contracts, Asset Ownership and Job Design," Journal of Law, Economics and Organization 7: 24-54.

Holmström, Bengt and John Roberts. 1998. "The Boundaries of the Firm Revisited," Journal of Economic Perspectives 12: 73-94.

Jones, Gareth R. 1983. “Transaction Costs, Property Rights, and Organizational Culture: An Exchange Perspective. _Administrative Science Quarterly 28: 454-467.

Kogut, Bruce and Udo Zander. 1992. "Knowledge of the Firm, Combinative Capabilities, and the Replication of Technology," Organization Science 3: 383397.

Kogut, Bruce and Udo Zander. 1993. "Knowledge of the Firm and the Evolutionary Theory of the Multinational Corporation," Journal of International Business Studies 24: 625-645.

Kogut, Bruce and Udo Zander. 1995. "Knowledge and the speed of the transfer and imitation of organizational capabilities: An empirical test," Organization Science 6/1: 76-91

Kogut, Bruce. 2000. "The Network as Knowledge: Generative Rules and the Emergence of Structure, " Strategic Management Journal 21: 405-425.

Laursen, Keld and Nicolai J Foss. 2003. “New HRM Practices, Complementarities, and the Impact on Innovation Performance," Cambridge Journal of Economics 27: 243-263.

Lindenberg, Sigward. 2003. "The Cognitive Side of Governance," Research in the Sociology of Organizations 20: 47-76.

Lippman, Steven A. and Richard P. Rumelt. 2003. "The Payments Perspective: Micro-Foundations of Resource Analysis," Strategic Management Journal 24: 903927. 
Loasby, Brian J. 1976. Choice, Complexity, and Ignorance. Cambridge: Cambridge University Press.

Lyles, Marjorie A. and Charles R. Schwenk. 1992. “Top Management Strategy and Organizational Knowledge," Journal of Management Studies 29(2): 155-174.

Maritan, C.A. and T.H. Brush. 2003. "Heterogeneity and Transferring Practices: Implementing Flow Manufacturing in Multiple Plants," Strategic Management Journal 24: 945-960.

Milgrom, Paul. 1988. "Employment Contracts, Influence Activities and Efficient Organization Design," Journal of Political Economy 96: 42-60.

Milgrom, Paul and John Roberts. 1990. “The Economics of Modern Manufacturing: Technology, Strategy and Organization," American Economic Review, 80: 511528.

Mowery, David C., Joanne Oxley, and Brian Silverman. 1996. "Strategic Alliances and Interfirm Knowledge Transfer," Strategic Management Journal 17: 77-91.

Mudambi, Ram, Susan M. Mudambi, and Pietro Navarra. 2003. "How to Motivate Knowledge Workers: An Empirical Investigation of Motivation Crowding Theory," Discussion Paper 716-03, The Fox School of Business and Management, Temple University.

Nelson, Richard R. and Sidney G. Winter. 1982. The Evolutionary Theory of the Firm. Cambridge, MA: Harvard University Press.

Nickerson, Jackson and Todd Zenger. 2004. "A Knowledge-based Theory of the Firm: The Problem-Solving Perspective," Organization Science 15(6): 617-632

Osterloh, Margit and Bruno Frey. 2000. "Motivation, Knowledge Transfer and Organizational Form," Organization Science 11: 538-550.

Oxley, Joanne. 1997. "Appropriability Hazards and Governance in Strategic Alliances: a Transaction Cost Approach," Journal of Law, Economics, and Organization 13: 387-409.

Prusac, Laurence. 1998. "Introduction to Series - Why Knowledge, Why Now?," in Daal Neef, ed., The Knowledge Economy. Boston: Butterworth-Heinemann.

Richardson, G. B. 1972. “The Organisation of Industry,” Economic Journal 82: 883-96

Rousseau, Denise M. and Zipi Shperling. 2003. "Pieces of the action: Ownership and the changing employment relationship," Academy of Management Review, 28: 553-570.

Samuelson, Larry. 2005. "Modeling Knowledge in Economic Analysis," Journal of Economic Literature 42: 367-403.

Shelanski, Howard A. and Peter G. Klein. 1995. "Empirical Research in Transaction Cost Economics: A Review and Assessment," Journal of Law, Economics and Organization 11 (2): 335-61. 
Spender, J.C. 1996. "Making Knowledge the Basis of a Dynamic Theory of the Firm," Strategic Management Journal 17 (Winter special issue): 45-62.

Spender, J.C. 2005. "Review Article: An Essay of the State of Knowledge Management," Prometheus 23: 101-116.

Starbuck, William. 1992. "Learning by Knowledge-Intensive Firms," Journal of Management Studies 29: 713-41.

Teece, David J. 2003. "Expert Talent and the Design of (Professional Services) Firms," Industrial and Corporate Change 12: 895-916.

Teece, David J., Gary Pisano and Amy Shuen. 1997. "Dynamic Capabilities and Strategic Management," Strategic Management Journal 18: 509-534.

Williamson, Oliver E. 1975. Markets and Hierarchies. New York: Free Press.

Williamson, Oliver E. 1996. The Mechanisms of Governance. Oxford: Oxford University Press.

Williamson, Oliver E. 1999. "Strategy research: Governance and competence perspectives," Strategic Management Journal, 20: 1087-1108.

Winter, Sidney G. 1987. "Knowledge and Competence as Strategic Assets" in The Competitive Challenge. D. Teece (ed.), 159-184. Cambridge, MA: Ballinger.

Winter, Sidney G. 2003. "Understanding Dynamic Capabilities," Strategic Management Journal 24: 991-995. 


\section{SMG - Working Papers \\ www.cbs.dk/smg \\ 2003}

2003-1: Nicolai J. Foss, Kenneth Husted, Snejina Michailova, and Torben Pedersen: Governing Knowledge Processes: Theoretical Foundations and Research Opportunities.

2003-2: Yves Doz, Nicolai J. Foss, Stefanie Lenway, Marjorie Lyles, Silvia Massini, Thomas P. Murtha and Torben Pedersen: Future Frontiers in International Management Research: Innovation, Knowledge Creation, and Change in Multinational Companies.

2003-3: Snejina Michailova and Kate Hutchings: The Impact of In-Groups and OutGroups on Knowledge Sharing in Russia and China CKG Working Paper.

2003-4: Nicolai J. Foss and Torben Pedersen : The MNC as a Knowledge Structure: The Roles of Knowledge Sources and Organizational Instruments in MNC Knowledge Management CKG Working Paper.

2003-5: Kirsten Foss, Nicolai J. Foss and Xosé H. Vázquez-Vicente: “Tying the Manager's Hands": How Firms Can Make Credible Commitments That Make Opportunistic Managerial Intervention Less Likely CKG Working Paper.

2003-6: Marjorie Lyles, Torben Pedersen and Bent Petersen: Knowledge Gaps: The Case of Knowledge about Foreign Entry.

2003-7: Kirsten Foss and Nicolai J. Foss: The Limits to Designed Orders: Authority under "Distributed Knowledge" CKG Working Paper.

2003-8: Jens Gammelgaard and Torben Pedersen: Internal versus External Knowledge Sourcing of Subsidiaries - An Organizational Trade-Off.

2003-9: Kate Hutchings and Snejina Michailova: Facilitating Knowledge Sharing in Russian and Chinese Subsidiaries: The Importance of Groups and Personal Networks Accepted for publication in Journal of Knowledge Management.

2003-10: Volker Mahnke, Torben Pedersen and Markus Verzin: The impact of knowledge management on MNC subsidiary performance: the role of absorptive capacity CKG Working Paper.

2003-11: Tomas Hellström and Kenneth Husted: Mapping Knowledge and Intellectual Capital in Academic Environments: A Focus Group Study Accepted for publication in Journal of Intellectual Capital CKG Working Paper.

2003-12: Nicolai J Foss: Cognition and Motivation in the Theory of the Firm: Interaction or "Never the Twain Shall Meet"? Accepted for publication in Journal des Economistes et des Etudes Humaines CKG Working Paper.

2003-13: Dana Minbaeva and Snejina Michailova: Knowledge transfer and expatriation practices in MNCs: The role of disseminative capacity.

2003-14: Christian Vintergaard and Kenneth Husted: Enhancing selective capacity through venture bases. 


\section{4}

2004-1: Nicolai J. Foss: Knowledge and Organization in the Theory of the Multinational Corporation: Some Foundational Issues

2004-2: Dana B. Minbaeva: HRM practices and MNC knowledge transfer

2004-3: Bo Bernhard Nielsen and Snejina Michailova: Toward a phase-model of global knowledge management systems in multinational corporations

2004-4: Kirsten Foss \& Nicolai J Foss: The Next Step in the Evolution of the RBV: Integration with Transaction Cost Economics

2004-5: Teppo Felin \& Nicolai J. Foss: Methodological Individualism and the Organizational Capabilities Approach

2004-6: Jens Gammelgaard, Kenneth Husted, Snejina Michailova: Knowledge-sharing Behavior and Post-acquisition Integration Failure

2004-7: Jens Gammelgaard: Multinational Exploration of Acquired R\&D Activities

2004-8: Christoph Dörrenbächer \& Jens Gammelgaard: Subsidiary Upgrading? Strategic Inertia in the Development of German-owned Subsidiaries in Hungary

2004-9: Kirsten Foss \& Nicolai J. Foss: Resources and Transaction Costs: How the Economics of Property Rights Furthers the Resource-based View

2004-10: Jens Gammelgaard \& Thomas Ritter: The Knowledge Retrieval Matrix: Codification and Personification as Separate Strategies

2004-11: Nicolai J. Foss \& Peter G. Klein: Entrepreneurship and the Economic Theory of the Firm: Any Gains from Trade?

2004-12: Akshey Gupta \& Snejina Michailova: Knowledge Sharing in Knowledge-Intensive Firms: Opportunities and Limitations of Knowledge Codification

2004-13: Snejina Michailova \& Kate Hutchings: Knowledge Sharing and National Culture: A Comparison Between China and Russia

\section{5}

2005-1: Keld Laursen \& Ammon Salter: My Precious - The Role of Appropriability Strategies in Shaping Innovative Performance

2005-2: Nicolai J. Foss \& Peter G. Klein: The Theory of the Firm and Its Critics: A Stocktaking and Assessment

2005-3: Lars Bo Jeppesen \& Lars Frederiksen: Why Firm-Established User Communities Work for Innovation: The Personal Attributes of Innovative Users in the Case of Computer-Controlled Music

2005-4: Dana B. Minbaeva: Negative Impact of Hrm Complementarity on Knowledge Transfer in Mncs

2005-5: Kirsten Foss, Nicolai J. Foss, Peter G. Klein \& Sandra K. Klein: Austrian Capital Theory and the Link Between Entrepreneurship and the Theory of the Firm 
2005-1: Nicolai J. Foss: The Knowledge Governance Approach 